\title{
Personal and professional profile, education, and perception of management and entrepreneurship of Dentistry students
}

\author{
Jaqueline Montoril Sampaio Mota*; Maria Ercilia de Araújo*; Fernanda Campos de Almeida Carrer*; Thais \\ Torralbo Lopez-Capp*; Maria Gabriela Haye Biazevic*; Edgard Michel-Crosato* \\ * Community Dentistry Department, School of Dentistry, \\ University of São Paulo
}

Received November 2, 2018. Approved December 21, 2018.

\begin{abstract}
In Dentistry, management and leadership seem to play an increasingly important role in facing the new challenges of the dental market. This study aimed to verify the personal profile for professional practice and the perception of management and entrepreneurship of students who attended the last year of Faculty of Dentistry, University of São Paulo, upon completion of the course of management and strategic planning in dentistry, for entering the labor market. A quantitatively and qualitatively descriptive cross-sectional study was conducted. A questionnaire with open and closed questions was applied to 109 students who attended the course of management and strategic planning in dentistry. This course had 109 students enrolled, and for this research, 107 (98.17\%) answered the questionnaire. The average age was 25 years, and $70.09 \%$ were female; $63.55 \%$ said they have a good knowledge of themselves. When asked whether they knew some personal characteristics of dentists who have achieved success, 50.47\% answered positively; $61.68 \%$ of students considered themselves organized, and $54.21 \%$ believed in being able to lead others. In the personal and professional profiles of students, it was possible to identify characteristics of leadership and optimism that they possessed about their professional future. Most of the students could incorporate attitudes and values that were covered by the course of management and strategic planning in dentistry. Additionally, the majority of them considered the knowledge acquired during this course while planning their professional careers.

Descriptors: Professional Role. Professional Practice. Practice Management. Entrepreneurship. Dentistry.
\end{abstract}

\section{INTRODUCTION}

The inclusion into the labor market is just the first challenge that recently graduated students will encounter when leaving the university. The recent change in the dental market increasingly requires dentists to be more 
qualified in the performance of their skills and competencies. These demands are not only about technical skills, but also encompass administrative and management related knowledge, either within the public or the private sphere.

In this way, the exercise of management and a leadership role in dentistry are extremely important in meeting new challenges and leading innovations and changes ${ }^{1}$. The literature shows the importance of the awareness of leadership in various aspects of dentistry, whether it be in clinical practice, in Dental education, research, or in public health ${ }^{2-7}$.

The management of the dental career has become increasingly important, such that students from the Harvard School of Dental Medicine (HSDM) have been requesting a course of management practice as part of the core curriculum, considering that the key to professional success is the building of a prosperous business ${ }^{8}$.

In Brazil, the National Curriculum Guidelines (NCG), which regulate and guide the core curriculum of universities, also understand that this is a vital topic for the training of a dental surgeon. After the implementation of the NCG, management and administration subjects are compulsory components in the core curriculum of dentistry courses ${ }^{9}$.

Considering this, the study aimed to verify the personal profile for professional practice and the perception of management and entrepreneurship of students who attended the last year of Faculty of Dentistry, University of São Paulo, upon their completion of the course of management and strategic planning in dentistry, for entering the labor market.

\section{MATERIALS AND METHODS}

This investigation is in accordance with the international and national ${ }^{10}$ parameters of ethics investigation with human beings; the investigation protocol was submitted and approved by the Ethics Committee of Faculty of Dentistry, University of São Paulo (CAAE: 35560314.1.0000.0075).

A quantitatively and qualitatively descriptive cross-sectional study was conducted. A questionnaire with open and closed questions was administered to 109 students who attended the senior year of Faculty of Dentistry, University of São Paulo, upon their completion of the course of management and strategic planning in Dentistry.

The questionnaire was administered on the last day of school, and an explanation about the study was provided to the students before they began answering the questions. The questionnaire had two parts: the first part formed a personal and professional profile of the students, and the second analyzed the perceptions of students towards entrepreneurship and management.

The data obtained from the closed questions were tabulated using the software Microsoft Office Excel 2011, and the software STATA 13.0 was used to analyze the data. The first step of the analysis was to present the data descriptively, using the frequency of distribution, measures of central tendency, and measures of dispersion. For the open questions, content analysis was performed.

\section{RESULTS}

The course of management and strategic planning in Faculty of Dentistry, University of São Paulo had 109 enrolled students. For this research, 107 (98.17\%) answered the questionnaire. The average age was 25 years and $70.09 \%$ were female.

With reference to career choices, only $4.67 \%$ of students had not chosen an alternative professional practice, and $61.68 \%$ said they 
believed the same would be fulfilled through this activity.

As for the self-knowledge, $63.55 \%$ said they possessed a good knowledge of themselves, and when asked whether they knew some personal characteristics of dentists who had achieved success, $50.47 \%$ answered positively. It was observed that $37.38 \%$ of students accepted running risks and $33.64 \%$ believed that they had ideas for a successful business. Most of the students also believed they were facing a real opportunity of reaching professional success. A large proportion of students $(42.06 \%)$ chose Dentistry partly because of financial issues, but this was not the only reason. A total of $58.88 \%$ of the students seek satisfaction in their vocation through their choices. Talking about the reasons that led them to choose this career, the following categories emerged: "self-fulfillment," "break of the routine," "need of specific training," and "opportunity" (table 1).

Table 1. Categories and index topics

\begin{tabular}{cl}
\hline Categories & \multicolumn{1}{c}{ Index topics } \\
\hline Self-fulfillment & $\begin{array}{l}\text { financial stability; independence from their parents; to have income; the } \\
\text { dream; delights; affinity; personal fulfillment; philosophy of life; } \\
\text { identification with the area of work; ability. }\end{array}$ \\
$\begin{array}{c}\text { Break of the } \\
\text { routine }\end{array}$ & $\begin{array}{l}\text { do not like the dental clinic routine; absence of routine; something new } \\
\text { or unexpected; turnover. }\end{array}$ \\
$\begin{array}{c}\text { Need of specific } \\
\text { training }\end{array}$ & $\begin{array}{l}\text { specific training; specialization; to gain experience; improvement in } \\
\text { training; confidence; to improve; master; research; academic career. }\end{array}$ \\
Opportunity & facility; practicality; to have a ready clinic influence; familiar practice. \\
\hline
\end{tabular}

With respect to organization, $61.68 \%$ of students consider themselves organized, and $54.21 \%$ believe in being able to lead others; $53.27 \%$ of students intend to attend a specialization course the following year, and $40.19 \%$ do not expect the same; and $58.88 \%$ do not plan to study for a postgraduate degree (table 2).

In the second part of the questionnaire, it was observed that $35.51 \%$ of students answered that they were able to clearly describe the objective of the organizations in which they would work, and $41.12 \%$ were aware of the main product of that organization.

The categories described in table 3 were collected using content analysis from the answers that were given by the students when they were requested to express their main features.

Regarding the profile of future patients, only $32.71 \%$ of respondents already know this profile, $30.84 \%$ believe they have instruments to gather information about this, $45.79 \%$ have forms to measure patient satisfaction, and $19.63 \%$ have strategies to attract new patients.

The study revealed that $66.36 \%$ of the students already chose the city in which they would start their professional careers, and $30.84 \%$ have defined their areas of action. Most students $(40.19 \%)$ have analyzed the importance of the location for their business, and $43.93 \%$ believe that the chosen place gives more credibility to the patient. Furthermore, $11.21 \%$ of 
students responded that the main feature of a dental supplier would be the price and $27.10 \%$ said they would have a business partner. When asked whether the main feature of the suppliers would be the quality, $51.40 \%$ answered affirmatively.

It was observed that most students have not thought about assistants, professional trainings, stimulus policy, and monthly costs pertaining to employees. Only $20.56 \%$ already know how these trainings would be, and $24.30 \%$ have thought about stimulus policies.

Most students (59.81\%) have not outlined any documents required to open a clinic, and $15.89 \%$ have thought about protocols to reduce civil lawsuits (table 4).

Table 2. Distribution of the students according to their personal profiles

\begin{tabular}{|c|c|c|c|c|}
\hline \multicolumn{5}{|c|}{ Part 1. Personal Profile } \\
\hline & Yes & $+/-$ & No & NA \\
\hline $\begin{array}{l}\text { Have you chosen for the next year an alternative of } \\
\text { professional performance? }\end{array}$ & $\begin{array}{l}68,22 \% \\
(73)\end{array}$ & $\begin{array}{l}27,10 \% \\
(29)\end{array}$ & $\begin{array}{l}4,67 \% \\
(5)\end{array}$ & - \\
\hline $\begin{array}{l}\text { Is the activity which you intend to do associated with } \\
\text { your self-fulfillment needs, and in accordance with } \\
\text { your personal characteristics, temperament, } \\
\text { preferences, psychological profile, skills, and status? }\end{array}$ & $\begin{array}{l}61,68 \% \\
\quad(66)\end{array}$ & $\begin{array}{l}33,64 \% \\
\quad(36)\end{array}$ & $\begin{array}{l}1,87 \% \\
(2)\end{array}$ & $\begin{array}{l}2,80 \% \\
(3)\end{array}$ \\
\hline $\begin{array}{l}\text { Have you already identified the reasons that led you } \\
\text { to carry out this activity? }\end{array}$ & $\begin{array}{l}75,70 \% \\
(81)\end{array}$ & $\begin{array}{l}20,56 \% \\
(22)\end{array}$ & $\begin{array}{l}1,87 \% \\
(2)\end{array}$ & $\begin{array}{l}1,87 \% \\
(2)\end{array}$ \\
\hline Do you know yourself? & $\begin{array}{l}63,55 \% \\
(68)\end{array}$ & $\begin{array}{l}34,58 \% \\
(37)\end{array}$ & $\begin{array}{l}0,93 \% \\
(1)\end{array}$ & $\begin{array}{l}0,93 \% \\
(1)\end{array}$ \\
\hline $\begin{array}{l}\text { Do you know some personal characteristics of } \\
\text { dentists who have achieved success? }\end{array}$ & $\begin{array}{l}50,47 \% \\
\quad(54)\end{array}$ & $\begin{array}{l}37,38 \% \\
\quad(40)\end{array}$ & $\begin{array}{c}12,15 \\
\%(13)\end{array}$ & - \\
\hline Do you accept running risks? & $\begin{array}{l}37,38 \% \\
\quad(40)\end{array}$ & $\begin{array}{l}38,32 \% \\
(41)\end{array}$ & $\begin{array}{c}18,69 \\
\%(20)\end{array}$ & $\begin{array}{l}5,61 \% \\
(6)\end{array}$ \\
\hline Do you have any idea of a good business? & $\begin{array}{l}33,64 \% \\
(36)\end{array}$ & $\begin{array}{l}40,19 \% \\
(43)\end{array}$ & $\begin{array}{l}26,56 \\
\%(22)\end{array}$ & $\begin{array}{l}5,61 \% \\
(6)\end{array}$ \\
\hline Are you organized? & $\begin{array}{l}61,68 \% \\
(66)\end{array}$ & $\begin{array}{l}28,04 \% \\
(30)\end{array}$ & $\begin{array}{l}8,41 \% \\
(9)\end{array}$ & $\begin{array}{l}1,87 \% \\
(2)\end{array}$ \\
\hline $\begin{array}{l}\text { I consider myself a creative person and I am curious } \\
\text { to know new things. }\end{array}$ & $\begin{array}{l}68,22 \% \\
(73)\end{array}$ & $\begin{array}{l}25,23 \% \\
(27)\end{array}$ & $\begin{array}{l}5,61 \% \\
(6)\end{array}$ & $\begin{array}{l}0,93 \% \\
\quad(1)\end{array}$ \\
\hline I have the ability to lead people. & $\begin{array}{l}54,21 \% \\
\quad(58)\end{array}$ & $\begin{array}{l}35,51 \% \\
(38)\end{array}$ & $\begin{array}{l}9,35 \% \\
(10)\end{array}$ & $\begin{array}{l}0,93 \% \\
\quad(1)\end{array}$ \\
\hline $\begin{array}{l}\text { Do you intend to attend a specialization course next } \\
\text { year? }\end{array}$ & $\begin{array}{l}53,27 \% \\
(57)\end{array}$ & $\begin{array}{l}5,61 \% \\
(6)\end{array}$ & $\begin{array}{l}40,19 \\
\%(43)\end{array}$ & $\begin{array}{l}0,93 \% \\
(1)\end{array}$ \\
\hline Do you intend to pursue a Masters or a $\mathrm{PhD}$ ? & $\begin{array}{l}27,10 \% \\
\quad(29)\end{array}$ & $\begin{array}{l}10,28 \% \\
(11)\end{array}$ & $\begin{array}{l}58,88 \\
\%(63)\end{array}$ & $\begin{array}{l}3,74 \% \\
(4)\end{array}$ \\
\hline
\end{tabular}


Table 3. Categories and index topics

\begin{tabular}{cl}
\hline Categories & \multicolumn{1}{c}{ Index topics } \\
\hline & practicality; creativity; optimizer; focus; patience; communicative; \\
& determination; leadership; to know how to work in groups; unafraid to \\
& undertake; proactive; attentive; committed; a high self-esteem; dedicated; \\
& ambitious; organized; friendly; good interpersonal relationships; \\
Positive points & responsible; involved; punctuality; demanding; perseverance; willingness; \\
& delight; listening skills; optimism; learn to delegate tasks; economic; \\
& applied; concentrated; flexibility; objectivity; fair; charismatic; sincerity; \\
& planned; perfectionism \\
Negative & lack of tolerance; anxiety; pushy; tight; disorganized; muddled; \\
points & temperamental; nervous; insecure; clumsy; shyness; difficulty in \\
& interacting; stubbornness; individualistic; authoritarian; lack of punctuality; \\
\hline
\end{tabular}

\section{DISCUSSION}

The Dental senior year students' profiles reveal that the majority of the students are female and young, consistent with the feminization process that has been observed in Brazil ${ }^{11}$ and in several other places in the world, such as in the United States and in Europa ${ }^{12-14}$.

Less than $5 \%$ of interviewees did not know where they would be working after graduation; this may indicate that students begin planning their professional career during the undergraduate course. Usually, in the final year of the degree, they are sure, or at least they can imagine as to how to go about getting a placement in the labor market.

It is important to note that more than half of these students made their choices to fulfill themselves. In a study conducted by the University of London, researchers found that $21 \%$ of their senior year students are still unsure of their professional choices ${ }^{14}$, and this result demonstrates that in this phase most students already know their professional future. On the other hand, Bastos et al. showed in their study that affinity and vocation were the primary motivation to the choice professionals and personal satisfaction was the lesser $^{15}$.

A few months before graduation, the students reflect and think about their professional future. For example, more than half say they know their skills and potential for the professional practice, and about half of them have already observed characteristics of successful practitioners in the fields they wish to work in.

The students also accept the possibility of taking some risks, and about one-third admit to having good ideas for their business. Besides, half of the students recognize in themselves characteristics of leadership. In dentistry, a lot of studies have been focused on the effect of leadership in this career, which showed that most students want to play a leading role in their professional career or in the community where they live ${ }^{1}$.

In Brazil, the NCG, that aim to guide the training of dentists, clarify the need for the development of abilities that go beyond the technique. The NCG also provide that the dentist must have administrative and management capacities in the same way as they should be able to be entrepreneurs, managers, employers, or 
Table 4. Distribution of the students according to the themes of the entrepreneur and organization

\begin{tabular}{|c|c|c|c|c|}
\hline \multicolumn{5}{|c|}{ Part 2. The entrepreneur and Organization } \\
\hline & Yes & $+/-$ & No & NA \\
\hline $\begin{array}{l}\text { Are you capable of clearly describing the goals of the } \\
\text { organization that you will work for? }\end{array}$ & $35,51 \%(38)$ & $41,12 \%(44)$ & $19,63 \%(21)$ & $3,74 \%(4)$ \\
\hline $\begin{array}{l}\text { Are you aware of what the main product of this } \\
\text { organization is? }\end{array}$ & $41,12 \%(44)$ & $35,51 \%(38)$ & $16,82 \%(18)$ & $6,54 \%(7)$ \\
\hline $\begin{array}{l}\text { Do you think that you are facing a real opportunity to } \\
\text { have a successful professional future? }\end{array}$ & $45,79 \%(49)$ & $44,86 \%(48)$ & $8,41 \%(9)$ & $0,93 \%(1)$ \\
\hline Do you know people who have chosen the same path? & $76,64 \%(82)$ & $5,61 \%(6)$ & $14,95 \%(16)$ & $2,80 \%(3)$ \\
\hline Do these people have professional success? & $70,09 \%(75)$ & $9,35 \%(10)$ & $1,87 \%(2)$ & $18,69 \%(20)$ \\
\hline $\begin{array}{l}\text { Will you follow this path mainly because of the } \\
\text { financial issue? }\end{array}$ & $58,88 \%(63)$ & $28,04 \%(30)$ & $11,21 \%(12)$ & $1,87 \%(2)$ \\
\hline Have you already established your main products? & $30,84 \%(33)$ & $24,30 \%(26)$ & $30,84 \%(33)$ & $14,02 \%(15)$ \\
\hline $\begin{array}{l}\text { Do you know what your competitive advantages over } \\
\text { the competition are? }\end{array}$ & $38,32 \%(41)$ & $32,71 \%(35)$ & $18,69 \%(20)$ & $10,28 \%(11)$ \\
\hline $\begin{array}{l}\text { Do you imagine what price customers are willing to } \\
\text { pay for the service? }\end{array}$ & $20,56 \%(22)$ & $48,60 \%(52)$ & $18,69 \%(20)$ & $12,15 \%(13)$ \\
\hline Do you imagine the profile of your main patients? & $50,47 \%(54)$ & $37,38 \%(40)$ & $6,54 \%(7)$ & $5,61 \%(6)$ \\
\hline Do you know who your competitors are? & $28,97 \%(31)$ & $30,84 \%(33)$ & $29,91 \%(32)$ & $10,28 \%(11)$ \\
\hline $\begin{array}{l}\text { Do you know which the main profile of your future } \\
\text { patients is? }\end{array}$ & $32,71 \%(35)$ & $49,53 \%(53)$ & $13,08 \%(14)$ & $4,67 \%(5)$ \\
\hline $\begin{array}{l}\text { Do you have tools to get information of the profiles of } \\
\text { future patients? }\end{array}$ & $30,84 \%(33)$ & $28,97 \%(31)$ & $31,78 \%(34)$ & $8,41 \%(9)$ \\
\hline Do you have ways to measure the patient satisfaction? & $45,79 \%(49)$ & $32,71 \%(35)$ & $14,02 \%(15)$ & $7,48 \%(8)$ \\
\hline $\begin{array}{l}\text { Have you programmed the marketing of your } \\
\text { business? }\end{array}$ & $16,82 \%(18)$ & $16,82 \%(18)$ & $48,60 \%(52)$ & $17,76 \%$ (19) \\
\hline $\begin{array}{l}\text { Do you already formulate strategies to win new } \\
\text { patients? }\end{array}$ & $19,63 \%(21)$ & $35,51 \%(38)$ & $30,84 \%(33)$ & $14,02 \%(15)$ \\
\hline Have you defined strategies to keep your patients? & $33,64 \%(36)$ & $27,10 \%(29)$ & $25,23 \%(27)$ & $14,02 \%(15)$ \\
\hline $\begin{array}{l}\text { You have the dental assistants required to perform } \\
\text { your activities }\end{array}$ & $20,56 \%(22)$ & $16,82 \%(18)$ & $42,06 \%(45)$ & $20,56 \%(22)$ \\
\hline $\begin{array}{l}\text { Have you considered how will be the training of these } \\
\text { professionals? }\end{array}$ & $20,56 \%(22)$ & $28,97 \%(31)$ & $41,12 \%(44)$ & $9,35 \%(10)$ \\
\hline $\begin{array}{l}\text { Have you already stipulated which will be the monthly } \\
\text { cost of these professionals? }\end{array}$ & $12,15 \%$ & $19,63 \%(21)$ & $55,14 \%(59)$ & $13,08 \%(14)$ \\
\hline Have you thought about stimulus policy? & $24,30 \%(26)$ & $15,89 \%(17)$ & $49,53 \%(53)$ & $10,28 \%(11)$ \\
\hline Have you already chosen the city to start your career? & $66,36 \%(71)$ & $9,35 \%(10)$ & $19,63 \%(21)$ & $4,67 \%(5)$ \\
\hline $\begin{array}{l}\text { Have you already chosen the location of your } \\
\text { business? }\end{array}$ & $30,84 \%(33)$ & $4,67 \%(5)$ & $49,53 \%(53)$ & $14,95 \%(16)$ \\
\hline $\begin{array}{l}\text { Have you analyzed the strategic importance of the } \\
\text { location? }\end{array}$ & $40,19 \%(43)$ & $19,63 \%(21)$ & $22,43 \%(24)$ & $17,76 \%(19)$ \\
\hline Does the location become credible to your patients? & $43,93 \%(47)$ & $17,76 \%(19)$ & $6,54 \%(7)$ & $31,78 \%(34)$ \\
\hline Have you defined which will be your main suppliers? & $10,28 \%(11)$ & $21,50 \%(23)$ & $51,40 \%(55)$ & $16,82 \%(18)$ \\
\hline Will the main feature of your suppliers be the price? & $11,21 \%(12)$ & $34,58 \%(37)$ & $36,45 \%(39)$ & $17,76 \%(19)$ \\
\hline Will the main feature of your suppliers be the quality? & $51,40 \%(55)$ & $23,36 \%(25)$ & $6,54 \%(7)$ & $18,69 \%(20)$ \\
\hline Will you have a partner? & $27,10 \%(29)$ & $11,21 \%(12)$ & $28,97 \%(31)$ & $32,71 \%(35)$ \\
\hline Have you already thought about social contract? & $11,21 \%(12)$ & $7,48 \%(8)$ & $57,01 \%(61)$ & $24,30 \%(26)$ \\
\hline $\begin{array}{l}\text { Have you already listed the documents to open your } \\
\text { business? }\end{array}$ & $11,21 \%(12)$ & $5,61 \%(6)$ & $59,81 \%(64)$ & $23,36 \%(25)$ \\
\hline
\end{tabular}


leaders of a health team ${ }^{9}$. The dental schools around the world have also been involved in discussions about the same topic and they are now including subjects such as Behavioral Science and Business in their curriculum ${ }^{16}$.

Most of our students are optimistic about their professional futures. They have already recognized an opportunity to succeed in their careers. Further, it is interesting to analyze that this success is not entirely related to financial returns, but also to their personal fulfillment. A study reveals that the majority of graduated women were satisfied with the dental practice, but more than half of them have complaints because of low pay, so the financial return cannot be a decisive factor in the initial choices of the future dentist. Over time it can give a certain degree of dissatisfaction, in so far as the same study reveals that most of these professionals do not encourage their children to follow the same professional path ${ }^{17}$.

On the other hand, the study of Rashid et $a l .{ }^{18}$ reveals that financial stability is crucial, and a very important factor in the choices that will be made by the future dentists, particularly among men.

Since 1970, the School of Dentistry from the University of São Paulo included a subject taught in the final semester, which aims to guide the careers of undergraduate students.

Some of the questions in the questionnaire were specific about contents that were provided during the management and strategic planning course in dentistry. These particular questions aimed to test the hypothesis that the students had become empowered due to the management and strategic planning contents. The data collected from these questions showed that some of the students could incorporate attitudes and values that were covered during the semester.
A third of the students know the purpose of the organization where they would work and half of them describe the main product of these companies. When asked if they would know to describe which reasons led them to desire this career, the qualitative data revealed these categories: "self-fulfillment," "break of the routine," "need of specific training," and "opportunity" (table 2). It was observed, however, that our students are able to define clearly and objectively the reasons for their choices and to establish these paths with maturity.

The need to gain professional experience after the undergraduate degree was also cited as the second most important factor when the discussion pertains to short-term career expectations $^{18}$.

Only slightly more than one-third of the respondents affirmed knowing their competitive advantages over the rest of the competition, and almost the same percentage have a partial knowledge of this. These data reveal that students have been developing an important market vision and this factor can be a differential for a successful career. However, nowadays, only a few schools have specific disciplines that talk about management, strategic planning, or economy in their curriculum ${ }^{19}$.

In connection with the care that the future dentist has in relation to the labor market, it is evident that the students are not concerned solely with opening a clinic and providing good clinical care. They are also concerned with a lot of other aspects, such as: who will be their clients, ways to adapt their services to the needs of the patient, the places for assisting their patients, costs, payment methods, marketing, and user satisfaction, among others. Nowadays, the labor market in dentistry is more competitive and 
requires more knowledge of management and economy than just technical skills ${ }^{19}$.

Studies reveal that most of the causes of burnout syndrome among dentists is due to the failure of these professionals in adequately managing their careers ${ }^{20-23}$. This fact clearly shows that the university has an obligation to discuss and empower their students on these subjects to increase their chances of success, and to improve their quality of life and well-being.

A fact that draws our attention is the low percentage of students who want to work with dental assistants in their professional practice. This can be explained as during the undergraduate course, they have few opportunities to work with dental assistants. The financial aspect could be another reason for this fact because they imagine being compelled to remunerate assistants in the early years of their careers.

Finally, although the students demonstrate knowledge of management aspects and strategic planning, the vast majority seemed not to realize what they learned during the course. This finding is quite justifiable since our sample was composed of senior students who had not yet entered the labor market, and the vast majority shall organize their career after graduation.

Further studies are required to understand better the mechanisms by which the teaching of management can contribute to the integration of students into the labor market. Longitudinal studies can provide new evidence on the impact of this subject in the performance of future health professionals.

\section{CONCLUSIONS}

In the personal and professional profiles of students, it was possible to identify leadership characteristics and optimism about their professional future. Most of the students could incorporate attitudes and values that were covered by the course of management and strategic planning in dentistry. Additionally, the majority of them consider the knowledge acquired during this course when planning their professional career.

As observed in other studies cited in this article, the teaching of management can influence the student's education process with the possibility of positively impacting their performance in the labor market.

\section{RESUMO}

Perfil pessoal e profissional, ensino e percepção sobre gestão e empreendedorismo de estudantes de Odontologia

$\mathrm{Na}$ Odontologia, a gestão e a liderança parecem desempenhar um papel cada vez mais importante no enfrentamento dos novos desafios do mercado odontológico. Este estudo teve como objetivo verificar o perfil pessoal para a prática profissional e a percepção de gestão e empreendedorismo de estudantes que cursavam o último ano da Faculdade de Odontologia da Universidade de São Paulo, ao finalizarem a disciplina de gerência e planejamento estratégico em Odontologia, para a entrada mercado de trabalho. Foi realizado um estudo transversal quantitativo e qualitativo descritivo. Um questionário com perguntas abertas e fechadas foi aplicado a 109 alunos que matriculados na disciplina de planejamento estratégico e gestão em Odontologia. Dos 109 alunos matriculados, 107 (98,17\%) responderam ao questionário. A idade média foi de 25 anos, e 70, 09\% eram do sexo feminino; $63,55 \%$ disseram ter um bom conhecimento de si mesmos. Quando perguntados se conheciam algumas características pessoais dos dentistas que alcançaram sucesso, $50,47 \%$ responderam positivamente; $61,68 \%$ dos estudantes se consideravam organizados e $54,21 \%$ acreditavam poder liderar outros profissionais. Nos perfis pessoal e profissional foi possível identificar características de liderança e otimismo em relação ao seu futuro profissional. A maioria incorporou atitudes e valores abordados pela disciplina. Além 
disso, a maioria considerou o conhecimento adquirido na disciplina no planejamento de suas carreiras profissionais.

Descritores: Função Profissional. Prática Profissional. Gerenciamento de Prática. Empreendedorismo. Odontologia.

\section{REFERENCES}

1. Victoroff KZ, Schneider K, Perry C. Leadership development for dental students: What do students think? J Dent Educ. 2008 Sep;72(9):982-8.

2. Christensen GJ. Fourteen characteristics of effective leaders in dentistry. J Am Coll Dent. 2004 Winter;71(4):18-21.

3. Levin R. The Dentist as a leader. J Am Dent Assoc. 2003;134:1391-2.

4. Roth K. Dental education: a leadership challenge for dental educators and practitioners. J Dent Educ. 2007;71(8):9837.

5. Turner SP, West KP. A qualitative comparison of women's leadership programs at local and national levels. J Dent Educ. 2006;70(11 Suppl):41-6.

6. Pinn VW. Women's health research and health leadership: benchmarks of the continuum. J Dent Educ 2006;70(11 Suppl):27-34.

7. Mouradian WE, Huebner C, DePaola D. Addressing health disparities through dental-medical collaborations. Part III: Leadership for the public good. J Dent Educ. 2004;68(5):505-12.

8. Kalenderian E, Skoulas A, Timothé $P$, Friedland B. Integrating leadership into a practice management curriculum for dental students. J Dent Educ. 2010 May;74(5):46471.

9. Brasil. Ministério da Saúde. Conselho Nacional de Educação. Câmara de Educação Superior. Resolução CNE/CES no 3, de 19 de fevereiro de 2002. Institui Diretrizes Curriculares Nacionais do Curso de Graduação em Odontologia. Brasília (DF): MEC, 2002.

10. Brasil. Ministério da Saúde. Conselho Nacional de Saúde. Comissão Nacional de Ética em Pesquisa. Resolução no 196/96. Brasília (DF): MS, 1996.

11. Morita MC, Haddad AE, de Araújo ME. Perfil atual e tendências do cirurgiãodentista brasileiro. Maringá: Dental Press, 2010.

12. McKay JC, Quiñonez

CR. The feminization of dentistry: implications for the profession. J Can Dent Assoc. 2012;78:c1.

13. Nkenke E, Seemann R, Vairaktaris E, Schaller HG, Rohde M, Stelzle F, Knipfer C. Gender trends in authorship in oral and maxillofacial surgery literature: A 30-year analysis. J Craniomaxillofac Surg. 2015 Jul;43(6):913-7.

14. Gallagher JE, Patel R, Wilson NH. The emerging dental workforce: long-term career expectations and influences. A quantitative study of final year dental students' views on their long-term career from one London Dental School. BMC Oral Health. 2009; Dec 23;9:35.

15. Bastos JR, Aquilante AG, Almeida BS, Lauris JR, Bijella VT. Professional profile analysis of dentists graduated at Bauru dental School - University of São Paulo between 1996 and 2000. J Appl Oral Sci. 2003 Dec;11(4):283-9.

16. Dunning DG, Lange BM, Madden RD, Tacha KK. Prerequisites in behavioral science and business: opportunities for dental education. J Dent Educ. 2011 Jan;75(1):77-81.

17. Moimaz SA, Saliba NA, Blanco MR. The women workforce in Dentistry in Araçatuba 
- SP. J Appl Oral Sci. 2003 Dec;11(4):3015.

18. Rashid HH, Ghotane SG, Abufanas SH, Gallagher JE. Short and long-term career plans of final year dental students in the United Arab Emirates. BMC Oral Health. 2013 Aug 13;13:39.

19. Willis DO. Using competencies to improve dental practice management education. J Dent Educ. 2009;73(10):1144-52.

20. Cooper CL. Psychological study. In: Cooper CL, Marshall, J. White collar and professional stress. Chichester: Wiley, 1980.

21. Dunlap JE, Stewart D. Suggestions to alleviate dental stress. Dent Econ. 1982; March:18-20.
22. Lewis KJ. Stress in dentistry. In: Davis HC, Forrest JO, Lewis KJ (eds). Review of dental practice III. Epsom: Morgan Publications, 1982.

23. Sebor RJ. Stress: inherent to dentists or taught to dental students? Dent Student. 1984;10:14-20.

\section{Correspondence to:}

Edgard Michel-Crosato

e-mail: michelcrosato@usp.br

Avenida Professor Lineu Prestes, 2227

05508-000 São Paulo/SP Brazil 